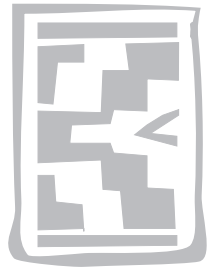

\title{
Tick infestation, and udder and teat damage in selected cattle herds of Matabeleland South, Zimbabwe
}

\author{
D.N. NDHLOVU1 ${ }^{1}$, P.V. MAKAYA² and B.L. PENZHORN ${ }^{1 *}$
}

\begin{abstract}
NDHLOVU, D.N., MAKAYA, P.V. \& PENZHORN, B.L. 2009. Tick infestation, and udder and teat damage in selected cattle herds of Matabeleland South, Zimbabwe. Onderstepoort Journal of Veterinary Research, 76:235-248

A cross-sectional survey was conducted to determine tick infestation, and udder and teat damage in 286 lactating cows and heifers at six properties in the smallholder and commercial sectors in Gwanda district of Matabeleland South Province, Zimbabwe. Eight tick species were identified: Amblyomma hebraeum, Hyalomma truncatum, Hyalomma marginatum rufipes, Rhipicephalus evertsi evertsi, Rhipicephalus (Boophilus) decoloratus, Rhipicephalus appendiculatus, Rhipicephalus zambeziensis and Rhipicephalus simus. Overall, $81.5 \%$ of the cattle were tick infested; prevalence of tick-infested cattle was significantly higher on communal land (93.8\%) and recently claimed land $(85.1 \%)$ than on commercial farms. The mean tick load on infested cattle on communal land was significantly higher than in the other two sectors. Although $53 \%$ of the sampled cattle had some degree of udder and teat damage, very few farmers $(2.6 \%)$ treated their cattle for these conditions. Udder damage was ca. two times and three times, respectively, more likely to occur in cattle on communal land compared to cattle on recently claimed land and commercial farms. The occurrence of $R$. appendiculatus and $R$. zambeziensis indicate that the cattle population in the study area is at high risk of a theileriosis outbreak, a tick-borne disease that has not been reported from this area.
\end{abstract}

Keywords: Teat damage, tick infestation, udder damage, Zimbabwe

\section{INTRODUCTION}

Tick infestation and tick-borne diseases (TBDs) are important conditions affecting livestock health and productivity in Zimbabwe (Norval 1979; Lawrence, Foggin \& Norval 1980) and in large areas of subSaharan Africa (Norval, Donachie, Meltzer, Deem \& Mahan 1995). Examples of major TBDs are anaplasmosis, babesiosis, heartwater and theileriosis.

* Author to whom correspondence is to be directed. E-mail: banie.penzhorn@up.ac.za

Department of Veterinary Tropical Diseases, Faculty of Veterinary Science, Private Bag X04, Onderstepoort, 0110 South Africa

2 Division of Veterinary Services, Central Veterinary Laboratory, Box CY 551 Causeway Harare, Zimbabwe

Accepted for publication 17 November 2008-Editor
Ticks are responsible for direct damage to livestock through their feeding habits. The damage is manifested as hide damage, damage to udders, teats and scrotum, myiasis due to infestation of damaged sites by maggots and secondary microbial infections (Norval 1983a; Meltzer \& Norval 1993; Dreyer, Fourie \& Kok 1998a). There are also productivity losses associated with the various tick species that can occur (Norval, Sutherst, Kurki, Gibson \& Kerr 1988; Norval, Sutherst, Jorgensen, Gibson \& Kerr 1989; Stachurski, Musonge, Achu-Kwi \& Saliki 1993; Meltzer, Norval \& Donachie 1995; Jonsson 2006). These are not usually obvious to the communal or smallholder farmer but are important if raising of cattle is done at a commercial level. Related to productivity losses, concepts such as economic damage threshold and economic threshold (Meltzer \& 
Norval 1993; Young \& Haantuba 1997) need to be considered in tick and TBD control. Meltzer \& Norval (1993) defined the economic damage threshold for Amblyomma hebraeum-infested cattle as the minimum average weekly standard female tick burden sufficient to cause damage, equal in dollar value to the cost of applying tick control. This figure can be changed due to damage to udders and teats, infestation of cattle by screwworm Chrysomya bezziana and the nutritional condition of the animal. According to Young \& Haantuba (1997), the economic threshold is the lowest pest population that causes a reduction in profit, or equivalently the pest population where the benefits of control equal the costs of eliminating the pest. Young \& Haantuba (1997) reported that the economic threshold for Rhipicephalus appendiculatus differed between infected and noninfected ticks. When infectious ticks were considered, then the economic threshold was reached even when only a single tick was present.

Compulsory short-interval dipping of cattle for the control of ticks and TBDs has been enforced in Zimbabwe since the early part of the previous century (Norval 1979; Norval 1983a; Norval, Perry \& Hargreaves 1992). Initially, intensive dipping was introduced for the control of East Coast fever following its introduction from East Africa in 1901/1902 during the restocking that followed the rinderpest pandemic of 1896 and the Anglo-Boer war of 1899-1902 (Norval 1979; Lawrence et al. 1980; Norval 1983a; Norval et al. 1992). As the ox-wagon was the main mode of transportation during this period, the pandemic had disastrous consequences. In recent years, the Division of Veterinary Services has faced budgetary constraints and has instituted strategic dipping to reduce costs. Strategic dipping entails weekly dipping of cattle during periods of high tick activity in the months of November to April and either fortnightly or monthly dipping during the other months. Plunge dipping with Amitraz $25.50 \% \mathrm{~m} / \mathrm{m}$ ("Tickbuster® WP", Zimbabwe Phosphate Industries) is practised in the communal areas. In the commercial sector farmers are responsible for the control of ticks and TBDs, and they usually practise intensive dipping regimens that are characterized by weekly dipping to ensure that cattle are tick-free. At the same time, vaccines are available for the control of anaplasmosis, babesiosis, Zimbabwean theileriosis and heartwater. These vaccines can be procured from the Central Veterinary Laboratory in Harare.

The agrarian land reform that started in full force in 2000 has seen movement of livestock into former commercial farms and the breakdown of fences between these commercial farms and communal areas. The above scenarios have implications as regards tick species dynamics, their impacts and their distribution in Matabeleland South Province, Zimbabwe.

The objective of this cross-sectional study was to characterize tick species, their distribution and their impact on cattle with special emphasis on udder and teat damage at selected dip-tanks and farms of Matabeleland South Province, Zimbabwe. Results from the study will add to existing knowledge, guide animal health managers and lay a foundation for further research on ticks and TBDs in Matabeleland South Province.

\section{MATERIALS AND METHODS}

\section{Study area and experimental animals}

The study was conducted in Gwanda district (Fig. 1) of Matabeleland South Province during the months of January, March and April 2007. A communalarea dip-tank, Switsha $\left(21^{\circ} 10^{\prime} \mathrm{S}, 2^{\circ} 07^{\prime} \mathrm{E}\right)$, was used as a pilot survey site to assess the completeness of the data-capture forms and to assess the ability to identify ticks by officers involved in the study. The other study properties were Timber Farm $\left(21^{\circ} 01^{\prime} \mathrm{S}, 2^{\circ} 09^{\prime} \mathrm{E}\right)$ and Double Cross Farm (21 $\left.1^{\circ} 10^{\prime} \mathrm{S}, 29^{\circ} 09^{\prime} \mathrm{E}\right)$, these two properties being A2 farms. New farmers who were formerly communal farmers own these two farms (A2 sector). The two commercial farms were Judds Farm (20 $53^{\prime} \mathrm{S}$,


which are owned and managed by the original farmers from before the land reform. In addition to Switsha dip tank, cattle from two communal dip-tanks were sampled: Sivume (20 $\left.36^{\prime} \mathrm{S}, 28^{\circ} 31^{\prime} \mathrm{E}\right)$ and Nyandeni $\left(20^{\circ} 40^{\prime} \mathrm{S}, 28^{\circ} 55^{\prime} \mathrm{E}\right)$. The study properties were all located in Natural Regions 4 and 5 of Zimbabwe (Tawonezvi 2005; International Crops Research Institute for the Semi-Arid Tropics [ICRISAT] 2007). This region is characterized by low and erratic rainfall of below $450 \mathrm{~mm}$ in Region 5 and of between $450 \mathrm{~mm}$ and $650 \mathrm{~mm}$ in Region 4 (ICRISAT 2007). Generally, in these regions, the year can be divided into three seasons: a warm, wet season from mid-November until April, a cool dry season from April to August and a hot dry season from September up to mid-November (Colborne, Norval \& Spickett 1981). According to ICRISAT (2007), the common vegetation type in Gwanda district is comprised of Colophospermum mopane, Combretum spp., Acacia spp., Boscia and Grewia spp. woodlands. The 




FIG. 1 Maps of Zimbabwe and Mattabeleland South Province showing study areas in Gwanda district

common grass species are Aristida and Panicum spp.

A total of 286 female cattle (lactating cows and heifers) were sampled. This does not include the 17 cattle that were sampled at Switsha dip tank during the pilot survey. The number of cattle sampled from each property was: Blanket Farm $n=34$, Double Cross Farm $n=46$, Judds Farm $n=39$, Timber Farm $n=21$, Nyandeni dip-tank $n=55$ and Sivume dip-tank $n=91$. The properties were chosen through convenient sampling, while the sample animals were sampled systematically (Thrusfield 1995) at the dip-tanks and farms. As absolute ages of individual animals were unknown, parity (i.e. number of calves borne) was used as an indicator of age.

\section{Tick counting, collection and identification}

Cattle were restrained in a cattle race for tick counts and tick collections. Counting of ticks was done on one side of the animal while all ticks on the udder were counted. The counting was done according to the method of Londt, Horak \& de Villiers (1979). The method targeted counting of ticks at their predilection sites on the live animal (Baker \& Ducasse 1967). No attempt was made to identify immature stages or to record gender of the ticks. Ticks were counted from six sites: both surfaces of the pinna, the neck region including the dewlap, the fore-leg including the axilla and hoof, upper perineum, the tail brush and the lower perineum which included the whole udder. At least two ticks of each species were collected by hand from the six predilection sites, of three visibly infested cattle after initial identification in situ, and preserved in $70 \%$ alcohol for confirmation of their identity under a stereo-microscope at the Central Veterinary Laboratory in Harare. Ticks from the same site on the animal and same dip-tank or farm were put in the same bottle, which was labelled with the collection date, site of collec- 
tion on the animal and the name of the property. Tick infestation was defined according to the Animal Health Act (Cattle Cleansing) Regulations, 1993 (Government of Zimbabwe 1993).

\section{Udder and teat damage}

Udder damage in this study was defined as conditions that affected the udder such as induration of one or more quarters, abscessation and open wounds. Udder damage was assessed by visual inspection, palpation to check for indurations and from the clinical history given by the owner of the animal. Further, it was also determined whether one or more quarters were affected. Farmers were verbally questioned on the methods they used to manage conditions affecting teats and udders; these questions were mainly directed to those farmers whose cattle had the condition of interest. The degree of udder damage was further graded as severe, mild, slight, none and other.

Teat damage was defined to include blocked teats, lost teats and teats from which milk containing pus could be expressed. The damage to teats was assessed by visual inspection, manual palpation and milking all quarters to check for blockages. Teat damage was graded as very severe, severe, mild, slight and none.

The information on tick numbers, tick species, udder damage, teat damage, treatment or non-treatment and parity of the animal (number of calves borne) were entered into two data-capture forms. One of the forms captured information on udder damage and teat damage, treatment/non-treatment and tick counts at the various predilection sites. The other form captured information on tick species and their numbers.

After field collection, the data were entered into Excel spreadsheets (Microsoft 2000). These data were also transformed into a database in Microsoft Access 2000.

The overall number of tick-infested cows and heifers was calculated from the total number of animals sampled and expressed as a percentage. Tick infestation was evaluated in relation to the farming sector, predilection site and parity of the animal. Udder and teat damage was assessed in relation to farming sector, parity and tick infestation status of the animal. Farming sector, predilection site and parity of the animal categories were generated as follows: three for farming sector (communal, A2 and commercial), six for predilection site (pinna, neck, leg, tail, upper and lower perineum) and three for parity $(1-3,4-6$ and $\geq 7)$.
The Two-Sample Proportion-Test and Two-Sample T-test for independent groups in Statistix (Analytical Software 1996, version 1.0) was used to measure differences in proportions between categories and to evaluate the differences in mean number of tick counts for the different categories, respectively. Values of $P<0.05$ were considered as significant.

Association between tick infestation and the potential putative risk factors and that between udder and teat damage and the potential putative risk factors was evaluated using Epi-Info Version 6. For tick infestation, the analysis focused on two risk factors, namely farming sector and parity of animal while that for udder and teat damage focused on farming sector, parity and tick infestation status of the animals. The association was assessed by calculating the chi-square $\left(\chi^{2}\right)$ test for association, the relative risk (RR) and $95 \%$ confidence intervals (Thrusfield 1995). An RR greater than 1 indicates a positive statistical association between factor and outcome, while that less than 1 indicates a negative statistical association and an RR of 1 suggests no association (Thrusfield 1995).

\section{RESULTS}

\section{Tick infestation according to farming sector, predilection site and parity of animals}

Of the 286 cows and heifers sampled, 233 (81.5\%) were infested with ticks (Table 1). The communal $(93.8 \%)$ and A2 (85.1\%) sectors recorded a significantly higher $(P<0.05)$ prevalence compared to the commercial farming sector (53.4\%); there was no significant difference between the former two farming sectors. Occurrence of tick infestation was significantly associated with the communal sector $\left(\chi^{2}=47.8, P<0.001\right)$ and the A2 sector $\left(\chi^{2}=14.8\right.$, $P<0.001)$ compared to the commercial sector. Tick infestation was found to be approximately two times more likely to occur on the communal sector $(R R=$ $1.8,1.4<\mathrm{RR}<2.2)$ and the A2 sector $(\mathrm{RR}=1.6$, $1.3<R R<2.02$ ) compared to the commercial farming sector.

Of the 8792 ticks counted in situ, the following species and groups were identified, in descending order of prevalence (Table 2): Amblyomma hebraeum (36 \%), Hyalomma truncatum/Hyalomma mariginatum rufipes (29\%), Rhipicephalus evertsi evertsi (17.7\%), Rhipicephalus (Boophilus) decoloratus (6.5\%), Rhipicephalus simus (5.4\%) and Rhipicephalus zambeziensis/appendiculatus (5\%).

Of the 8792 ticks counted, the communal sector $(70 \%)$ contributed the highest percentage with the 
A2 and commercial sectors together contributing $30 \%$ (Table 3). The tick index varied among the farming sectors with the communal sector (42.2) recording the highest index followed by the A2 (19.4) and the commercial sector recording the lowest (Table 3). Similarly, the mean tick counts varied significantly $(P<0.05)$ among the farming sectors (Table 3); irrespective of the tick species, the communal sector recorded a significantly overall higher mean tick count compared to the A2 and commercial sectors. However, there was no significant overall mean tick count difference between the $\mathrm{A} 2$ and commercial sectors. Significantly $(P<0.05)$ higher mean counts of $A$. hebraeum, $H$. truncatum and $R$. e. evertsi were recorded for the communal sector compared to the $\mathrm{A} 2$ and commercial farming sectors (Table 3 ). However, $A$. hebraeum mean tick count was significantly higher for the A2 sector compared to the commercial sector while that for $R$. $e$. evertsi was significantly higher for the commercial sector compared to the A2 sector. There was no significant difference in the mean tick count of $H$. truncatum between the A2 and commercial sectors. There was no significant difference in the mean tick count

TABLE 1 Number of cattle infested with ticks and the prevalence of tick infestation according to farming sector

\begin{tabular}{|l|l|l|l|}
\hline Farming sector & No. of cattle sampled & No. of cattle infested & Prevalence (\%) \\
\hline Communal & 146 & 137 & $93.8^{\mathrm{a}}$ \\
A2 & 67 & 57 & $85.1^{\mathrm{a}}$ \\
Commercial & 73 & 39 & $53.4^{\mathrm{c}}$ \\
\hline Total & $\mathbf{2 8 6}$ & $\mathbf{2 3 3}$ & $\mathbf{8 1 . 5}$ \\
\hline
\end{tabular}

Figures with a different superscript in a column are significantly different at $P<0.05$

TABLE 2 Total tick counts according to tick species identified by visual inspection

\begin{tabular}{|l|l|l|}
\hline Tick species & Total tick count & $\%$ \\
\hline A. hebraeum & 3165 & 36.0 \\
H. truncatum & 2575 & 29.3 \\
R. e. evertsi & 1559 & 17.7 \\
R. (B). decoloratus & 574 & 6.5 \\
R. simus & 477 & 5.4 \\
R. zambeziensis** & 442 & 5.0 \\
\hline Total & $\mathbf{8 7 9 2}$ & \\
\hline
\end{tabular}

* Includes H. m. rufipes

** Includes $R$. appendiculatus

TABLE 3 Total tick counts, mean tick counts and tick index according to farming sector and tick species identified by visual inspection

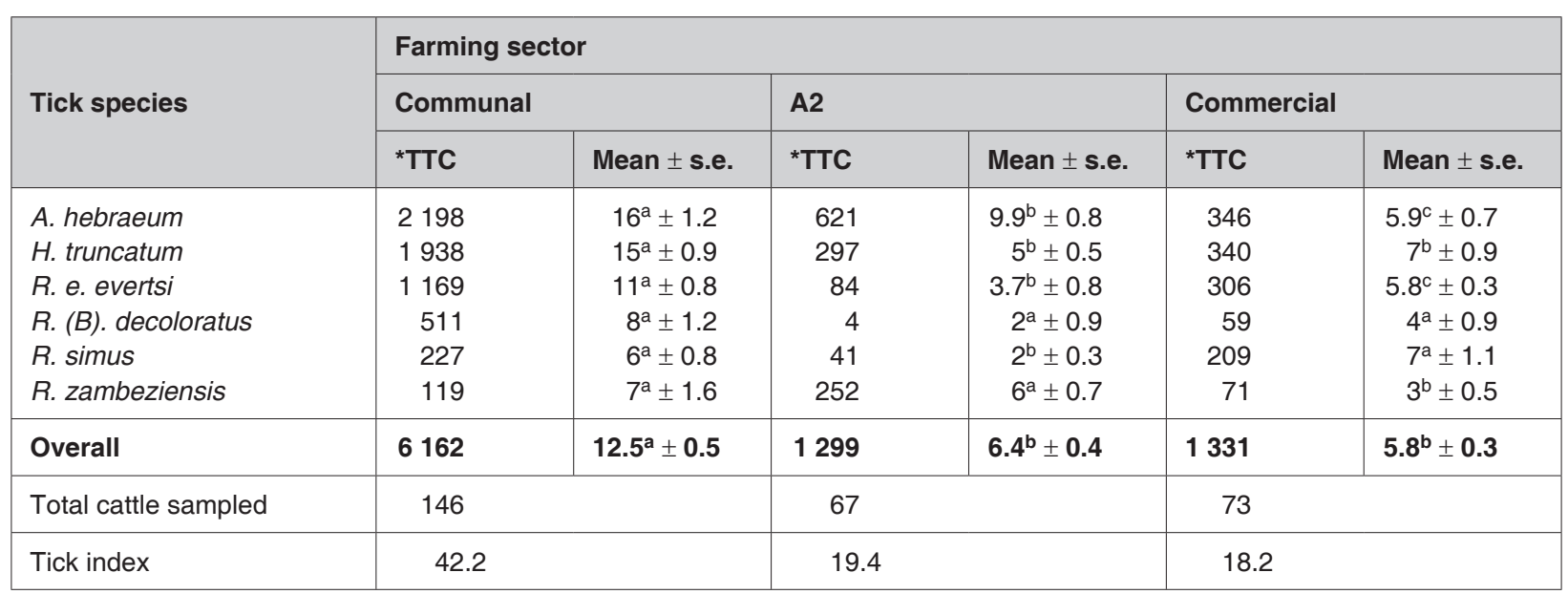

Mean tick counts with a different superscript in a row for each tick species are significantly different at $P<0.05$

* TTC $=$ Total tick count 
of $R$. (B). decoloratus among all the farming sectors. Rhipicephalus simus recorded a significantly lower mean tick count for the A2 sector compared to the commercial and communal sectors while that for $R$. zambeziensis was significantly lower for the commercial sector compared to the A2 and communal sectors.

The upper perineum accounted for the highest percentage $(34.3 \%)$ of the ticks counted in situ, followed by the lower perineum $(26.9 \%)$ with the leg $(6.2 \%)$ accounting for the lowest percentage (Table 4). Mean tick counts varied significantly $(P<0.05)$ according to the predilection site (Table 4); irrespective of the tick species, the upper and lower perineum recorded significantly higher mean tick counts compared to the other sites. The tail and the pinna also recorded significantly higher mean tick counts compared to the neck and the leg.

Tick samples that were sent to the Central Veterinary Laboratory (Table 5) revealed that $R$. zambeziensis was present at all sampled sites, while $R$. appendiculatus was only present at three sites. Other tick species, which were confirmed at the laboratory, were $H$. m. rufipes, which was identified from all the sites but Sivume dip tank and $H$. truncatum, which was identified at four sites, but not at Judds Farm.
The highest percentage of $A$. hebraeum and $R$. appendiculatus was recorded on the lower perineum while that of $R$. e. evertsi and $H$. m. rufipes was on the upper perineum, that for $R$. $(B)$. decoloratus, $R$. simus and $H$. truncatum was on the tail and that for R. zambeziensis was on the pinna (Table 6).

There was no significant difference in the prevalence of tick infestation according to parity (Table 7).

\section{Udder and teat damage according to farming sector and parity of animals}

The communal sector recorded a significantly higher $(P<0.05)$ prevalence of udder and teat damage compared to the A2 and commercial farming sectors and there was also a significant difference between the latter two sectors (Table 8). Occurrence of udder damage was significantly associated with the communal sector compared to the $\mathrm{A} 2\left(\chi^{2}=21\right.$, $P<0.001)$ and commercial sectors $\left(\chi^{2}=49, P<\right.$ 0.001 ). Similarly, teat damage was significantly associated with the communal sector compared to the A2 $\left(\chi^{2}=22.3, P<0.001\right)$ and commercial sectors $\left(\chi^{2}=64.8, P<0.001\right)$. Teat damage was also significantly associated with the $\mathrm{A} 2$ sector $\left(\chi^{2}=8.6, P\right.$ $=0.003$ ) compared to the commercial sector.

TABLE 4 Total, percent and mean tick counts of ticks identified visually according to predilection site on sampled animals

\begin{tabular}{|l|l|l|l|}
\hline Predilection site & Total tick count & \% of total & Mean \pm s.e \\
\hline Upper perineum & 3016 & 34.3 & $11.8^{\mathrm{a}} \pm 0.6$ \\
Lower perineum & 2358 & 26.9 & $10.1^{\mathrm{a}} \pm 0.6$ \\
Tail & 1252 & 14.2 & $7.6^{\mathrm{b}} \pm 0.6$ \\
Pinna & 952 & 10.8 & $6.7^{\mathrm{b}} \pm 0.5$ \\
Neck & 669 & 7.6 & $4.8^{\mathrm{c}} \pm 0.5$ \\
Leg & 545 & 6.2 & $4.2^{\mathrm{c}} \pm 0.3$ \\
\hline Total & $\mathbf{8 7 9 2}$ & \\
\hline
\end{tabular}

Mean tick counts with a different superscript in a column are significantly different at $P<0.05$

TABLE 5 Specimens identified by the Central Veterinary Laboratory

\begin{tabular}{|c|c|c|c|c|c|c|}
\hline \multirow{2}{*}{ Tick species } & \multicolumn{5}{|c|}{ Diptank/farm } & \multirow{2}{*}{ Total } \\
\hline & Switsha & Double Cross & Judds & Nyandeni & Sivume & \\
\hline A. hebraeum & 26 & 4 & 2 & * & 1 & 33 \\
\hline R. evertsi evertsi & * & 2 & 1 & * & 3 & 6 \\
\hline R. appendiculatus & 0 & 0 & 1 & 1 & 11 & 13 \\
\hline R. zambeziensis & 11 & 20 & 3 & 5 & 2 & 41 \\
\hline R. (B.) decoloratus & 0 & 0 & 18 & 0 & 17 & 35 \\
\hline R. simus & 1 & 11 & 5 & 3 & 6 & 26 \\
\hline H. truncatum & 6 & 5 & 0 & 5 & 11 & 27 \\
\hline H. marginatum rufipes & 6 & 3 & 2 & 5 & 0 & 16 \\
\hline Total ticks counted & 50 & 45 & 32 & 19 & 51 & 197 \\
\hline
\end{tabular}

* Not submitted 
TABLE 6 Predilection site of laboratory-identified tick species

\begin{tabular}{|c|c|c|c|c|c|c|c|c|c|}
\hline \multirow[b]{2}{*}{ Predilection site } & \multicolumn{8}{|l|}{ Tick species } & \multirow[b]{2}{*}{$\begin{array}{l}\text { Total } \\
\text { (\%) }\end{array}$} \\
\hline & $\begin{array}{l}\text { A. hebraeum } \\
\text { (\%) }\end{array}$ & $\begin{array}{l}\text { R. e. evertsi } \\
\text { (\%) }\end{array}$ & $\begin{array}{l}\text { R. zambezi- } \\
\text { ensis } \\
(\%)\end{array}$ & $\begin{array}{l}\text { R. appendicu- } \\
\text { latus } \\
(\%)\end{array}$ & $\begin{array}{l}\text { R. (B). } \\
\text { decoloratus } \\
(\%)\end{array}$ & $\begin{array}{l}\text { R. simus } \\
\text { (\%) }\end{array}$ & $\begin{array}{l}\text { H. truncatum } \\
\text { (\%) }\end{array}$ & $\begin{array}{l}\text { H. rufipes } \\
\text { (\%) }\end{array}$ & \\
\hline Upper perineum & $3(9.1)$ & $5(83.3)$ & $2(4.9)$ & 0 & $6(17.1)$ & 0 & $3(11.1)$ & $14(87.5)$ & $33(16.8)$ \\
\hline Lower perineum & $18(54.5)$ & 0 & $1(2.4)$ & $9(69.2)$ & $3(8.6)$ & $1(3.8)$ & $4(14.8)$ & 0 & $36(18.3)$ \\
\hline Tail & $5(15.2)$ & $1(16.7)$ & $4(9.8)$ & $1(7.7)$ & $11(31.4)$ & $23(88.5)$ & $14(51.9)$ & $2(12.5)$ & $61(31.0)$ \\
\hline Pinna & 0 & 0 & $21(51.2)$ & $1(7.7)$ & $1(2.9)$ & 0 & 0 & 0 & $23(11.7)$ \\
\hline Neck & $1(3)$ & 0 & $13(31.7)$ & $2(15.4)$ & $6(17.1)$ & 0 & $2(7.4)$ & 0 & $24(12.2)$ \\
\hline Leg & $6(18.2)$ & 0 & 0 & 0 & $8(22.9)$ & $2(7.7)$ & $4(14.8)$ & 0 & $20(10.2)$ \\
\hline Total & 33 & 6 & 41 & 13 & 35 & 26 & 27 & 16 & 197 \\
\hline
\end{tabular}


Tick infestation and udder and teat damage in cattle of Matabeleland South, Zimbabwe

Udder damage was found to be approximately two times and three times more likely to occur on the communal sector $(\mathrm{RR}=1.8,1.4<\mathrm{RR}<2.5$; $\mathrm{RR}=$ $3.2,2.1<\mathrm{RR}<4.9$ ) compared to the A2 and commercial farming sectors, respectively. Similarly, teat damage was found to be approximately two times and four times more likely to occur on the communal sector $(R R=1.8,1.4<R R<2.5 ; R R=4.3,2.6<R R$ $<7.1)$ compared to the A2 and commercial farming sectors, respectively. Teat damage was also found

TABLE 7 Number of cattle infested with ticks and the prevalence of tick infestation according to parity

\begin{tabular}{|l|l|l|l|}
\hline Parity & Total sample & Number infested & Prevalence (\%) \\
\hline $1-3$ & 199 & 162 & $81.4^{\mathrm{a}}$ \\
$4-6$ & 80 & 65 & $81.3^{\mathrm{a}}$ \\
$\geq 7$ & 7 & 6 & $85.7^{\mathrm{a}}$ \\
\cline { 2 - 3 } & $\mathbf{2 8 6}$ & $\mathbf{2 3 3}$ & \\
\hline
\end{tabular}

Figures with a different superscript in a column are significantly different at $P<0.05$

TABLE 8 Number and proportion of cows and heifers with udder and teat damage according to farming sector

\begin{tabular}{|l|l|l|l|}
\hline Farming sector & Total sampled & Udder damage (\%) & Teat damage (\%) \\
\hline Communal & 146 & $108\left(74.0^{\mathrm{a}}\right)$ & $111\left(76.0^{\mathrm{a}}\right)$ \\
A2 & 67 & $27\left(40.3^{\mathrm{b}}\right)$ & $28\left(41.8^{\mathrm{b}}\right)$ \\
Commercial & 73 & $17\left(23.3^{\mathrm{c}}\right)$ & $13\left(17.8^{\mathrm{c}}\right)$ \\
\hline Total & $\mathbf{2 8 6}$ & $\mathbf{1 5 2 ( 5 3 . 1 )}$ & $\mathbf{1 5 2}(\mathbf{5 3 . 1})$ \\
\hline
\end{tabular}

Figures with a different superscript in a column are significantly different at $P<0.05$

TABLE 9 Number and proportion of cows and heifers with udder and teat damage according to parity

\begin{tabular}{|l|l|l|l|}
\hline Parity & Total sampled & Udder damage (\%) & Teat damage (\%) \\
\hline $1-3$ & 199 & $115\left(57.8^{\mathrm{a}}\right)$ & $117\left(58.8^{\mathrm{a}}\right)$ \\
$4-6$ & 80 & $33\left(41.3^{\mathrm{b}}\right)$ & $29\left(36.3^{\mathrm{b}}\right)$ \\
$\geq 7$ & 7 & $4\left(57.1^{\mathrm{ab}}\right)$ & $4\left(57.1^{\mathrm{ab}}\right)$ \\
\hline Total & $\mathbf{2 8 6}$ & $\mathbf{1 5 2 ( 5 3 . 1 )}$ & $\mathbf{1 5 0}(\mathbf{5 2 . 4})$ \\
\hline
\end{tabular}

Figures with a different superscript in a column are significantly different at $P<0.05$

TABLE 10 Tick infestation and udder damage situation of sampled animals

\begin{tabular}{|l|l|l|}
\hline Tick infestation and udder damage status & $\begin{array}{l}\text { Number of animals } \\
\text { (Total animals tick infested/not tick infested) }\end{array}$ & $\%$ \\
\hline Tick infested animals with udder damage & $133(233)$ & 57.1 \\
Tick infested animals with no udder damage & $100(233)$ & 42.9 \\
Not tick infested animals with udder damage & $19(53)$ & 35.8 \\
Not tick infested animals with no udder damage & $34(53)$ & 64.2 \\
\hline
\end{tabular}

TABLE 11 Tick infestation and teat damage situation of sampled animals

\begin{tabular}{|l|l|l|}
\hline Tick infestation and teat damage status & $\begin{array}{l}\text { Number of animals } \\
\text { (Total animals tick infested/not tick infested) }\end{array}$ & $\%$ \\
\hline Tick infested animals with teat damage & $135(233)$ & 57.9 \\
Tick infested animals with no teat damage & $98(233)$ & 42.1 \\
Not tick infested animals with teat damage & $17(53)$ & 32.1 \\
Not tick infested animals with no teat damage & $36(53)$ & 67.9 \\
\hline
\end{tabular}


to be approximately two times more likely to occur on the A2 sector $(R R=2.4,1.3<R R<4.1)$ compared to the commercial sector.

Animals of parity $1-3$ recorded a significantly higher $(P<0.05)$ prevalence of udder and teat damage compared to those of parity 4-6, but there was no significant difference between those of parity 1-3 and parity $\geq 7$ and those of parity $4-6$ and parity $\geq$ 7 (Table 9). Occurrence of udder $\left(\chi^{2}=5.6, P=0.02\right)$ and teat $\left(\chi^{2}=10.7, P<0.001\right)$ damage was significantly associated with parity 1-3 compared to parity 4-6. Udder $(R R=1.4,1.1<R R<1.9)$ and teat $(R R$ $=1.6,1.2<\mathrm{RR}<2.2$ ) damage was found to be 1.4 times and approximately two times more likely to occur on animals of parity 1-3 compared to those of parity 4-6, respectively.

\section{Association between tick infestation and udder and teat damage}

The percentage of tick-infested animals with udder damage was higher than those with tick infestation but with no udder damage (Table 10).

Similarly, the percentage of tick-infested animals with teat damage was higher than those with tick infestation but with no teat damage (Table 11).

Occurrence of udder $\left(\chi^{2}=5.5, P=0.02\right)$ and teat $\left(\chi^{2}\right.$ $=10.6, P<0.001)$ damage was significantly associated with tick infestation compared to no tick infestation. Udder $(\mathrm{RR}=1.6,1.04<\mathrm{RR}<2.2)$ and teat $(R R=1.8,1.2<R R<2.7)$ damage was found to be approximately two times more likely to occur on tickinfested animals compared to those with no tick infestation.

\section{Treatment for udder and or teat damage}

Only four animals were treated out of a total of 152 cattle with udder and teat damage. The properties where treatment was given were Blanket Farm and Double cross Farm.

\section{DISCUSSION}

\section{Tick species and infestation}

Eight species of ticks were found to be infesting cattle at the different study sites. The ticks belonged to three genera, namely Amblyomma, Rhipicephalus (including the subgenus Boophilus) and Hyalomma. According to Punyua, Latif, Nokoe \& Capstick (1991), cited by Hlatshwayo, Mbati \& Dipeolu (2002), it is rare to find more than six species infesting their hosts in any one given ecological zone. In this case, eight species of ticks were found infesting cattle, which indicated that the study area probably comprised of two or more ecological zones. On the other hand, this could be one of those rare instances where more than six tick species are found in one ecological zone, as was evident at Judds Farm, Sivume dip tank and Nyandeni dip tank, where seven tick species were identified at the same study sites. Related species such as $R$. appendiculatus and $R$. zambeziensis, as well as $H$. truncatum and $H$. marginatum rufipes, coexisted at these sites.

In descending order of abundance, the tick species identified were A. hebraeum, Hyalomma sp., R. e. evertsi, $R$. (B.) decoloratus, $R$. simus and the R. appendiculatus/zambeziensis group. These findings are partly in agreement with those of Bryson, Tice, Horak, Stewart \& Du Plessis (2002) who found that in some parts of South Africa, particularly in the North West Province, the commonest ticks infesting cattle were $A$. hebraeum, $R$. appendiculatus and $R$. e. evertsi while in Mpumalanga Province the commonest tick was $R$. (B.) decoloratus. These findings are in contrast to those of several workers (Dreyer, Fourie \& Kok 1998a; Mekonnen, Hussein \& Bedane 2001; Hlatshwayo et al. 2002) who found that the commonest tick species infesting cattle was $R$. (B.) decoloratus in some parts of the Free State province of South Africa and in central Ethiopia. Regassa (2001) found the commonest tick in the Borana province of Ethiopia to be Rhipicephalus pulchellus.

\section{Amblyomma hebraeum}

The occurrence of $A$. hebraeum in this part of the country and the absence of Amblyomma variegatum is in agreement with the findings of Peter, Perry, O'Callaghan, Medley, Shumba, Madzima, Burridge \& Mahan (1998a). According to these authors, the northern limit of $A$. hebraeum is latitude $17^{\circ}$ South, while above this northern limit it is replaced by $A$. variegatum. Peter, Perry, O'Callaghan, Medley, Shumba, Madzima, Burridge \& Mahan (1998b) also reported that $A$. hebraeum was predominant in the lowveld and had encroached into some parts of the highveld of Zimbabwe. The absence of the related species, A. variegatum, was expected as its distribution is limited to the Zambezi valley and the surrounding dry lowveld areas in the north-western parts of Zimbabwe (Norval, Perry, Meltzer, Kruska \& Booth 1994). In the east, it is found in the Burma valley, which is at the eastern border of Zimbabwe (Norval 1983b). Amblyomma hebraeum and A. variegatum in Zimbabwe have an area of overlap (Peter 
et al.1998a). In an area of overlap there is inter-specific mating with the production of sterile hybrids. It is also reported that $A$. variegatum completely replaces $A$. hebraeum over a period of three years (Norval et al. 1994). The survival of $A$. hebraeum is favoured by the presence of alternative wildlife hosts for the adult stage while this is limited to African buffalo (Syncerus caffer) for $A$. variegatum (Norval et al. 1994). Petney, Horak \& Rechav (1987) stated that the main host species of $A$. hebraeum vary from place to place, with hosts of more than $100 \mathrm{~kg}$ in mass being regularly infested, while hosts below this mass are not usually infested. The immature stages infest birds and small mammals (Horak, Maclvor, Petney \& De Vos 1987). Amblyomma hebraeum has also been found to infest the leopard tortoise (Geochelone pardalis) and the angulate tortoise (Chersina angulata) (Dower, Petney \& Horak 1988). Amblyomma spp. ticks are important vectors of Ehrlichia ruminantium, the cause of heartwater (Peter et al. 1998b).

\section{Hyalomma species}

Two species, $H$. truncatum and $H$. marginatum rufipes, were collected in this study, while Chatikobo, Kusina, Hamudikuwanda \& Nyoni (2001) collected only $H$. m. rufipes from cattle in the Sanyati smallholder farming area in the north-western part of Zimbabwe. Horak, Swanepoel \& Gummow (2001) and Van Niekerk, Fourie \& Horak (2006) reported the presence of $H$. truncatum, $H$. m. rufipes, $H$. glabrum and $H$. marginatum turanicum in South Africa. Hyalomma glabrum and $H$. $m$. turanicum were not recovered during the current study.

Hyalomma truncatum and $H$. m. rufipes occurred together at $80 \%$ of the study sites, which is in agreement with Van Niekerk et al. (2006) who stated that there was considerable overlap in the distributions of $H$. truncatum and $H$. m. rufipes. The upper perineum was the attachment site of $87.5 \%$ of $H$. m. rufipes, while $12.5 \%$ were collected from the tail. This tick did not infest the other parts of the animal. This study confirmed the predilection site for $H$. $m$. rufipes to be the upper perineum, in agreement with Baker \& Ducasse (1967) and Londt et al. (1979). The related $H$. truncatum was collected at $80 \%$ of the study sites. The majority of the ticks, ca. $52 \%$, were collected from the tail, while all attachment sites on the animal, except for the pinna, yielded ticks. These findings differ slightly from those of Londt et al. (1979) who collected the tick from all six predilection sites, with most of the ticks being collected from the upper perineum.

\section{Rhipicephalus evertsi evertsi}

The occurrence $R$. e. evertsi at all sites was consistent with the findings of Norval (1981) who reported that this tick species occurred in all parts of Zimbabwe except in the Zambezi valley. This tick is able to tolerate a wide range of climatic conditions (Hamel \& Gothe 1978) and some strains can cause paralysis in sheep.

\section{Rhipicephalus (Boophilus) decoloratus}

With the exception of Double Cross Farm, Rhipicephalus (Boophilus) decoloratus was found at all study sites. The failure to find $R$. (B.) decoloratus at Double Cross Farm could have been because cattle had been dipped three days previously and as such this tick could have been removed by the acaricide. Cattle are the main hosts of $R$. (B.) decoloratus (Londt et al. 1979), with horses and donkeys being less important hosts. This tick can also be found on a large number of wild ungulates, including impalas (Aepyceros melampus), bushbuck (Tragelaphus scriptus) and kudus (Tragelaphus strepsiceros) (Horak, Potgieter, Walker, De Vos \& Boomker 1983). The species is distributed throughout most of the wetter regions of South Africa and is present in the eastern parts of Zimbabwe (Norval et al. 1992; Walker, Bouattour, Camicas, Estrada-Peña, Horak, Latif, Pegram \& Preston 2003). The related R. (B.) microplus was not found in this lowveld area. The absence of $R$. (B.) microplus was expected, as it has a limited distribution in Zimbabwe (Katsande, Mazhowu, Turton \& Munodzana 1996); distribution of this tick is in the eastern region (Chimanimani, Chipinge, Mutare, Rusape and Wedza), northern, north-eastern and the north-western region of Zimbabwe (Katsande et al. 1996).

\section{Rhipicephalus simus}

This tick species was collected from all study sites. As expected, the bulk of the collections (ca. $88 \%$ ) were from the tail switch. These findings are similar to those of Londt et al. (1979), where $100 \%$ of the ticks were collected from the tail switch. Interestingly, $R$. simus was found in large numbers on some properties during this study; in contrast, Bryson et al. (2002) indicated that while this tick was widely distributed, it was seldom found in large numbers. The large numbers identified at some study sites would indicate that there was an abundance of murid rodents in the area, which are the hosts for the immature stages of this tick species (Walker et al. 2003; Van Niekerk et al. 2006). The other reason for the 
abundance would be the dipping method: if farmers do not thoroughly wet the tail switch or ignore it completely, then this tick would thrive.

\section{Rhipicephalus appendiculatus and Rhipicephalus zambeziensis}

These two species co-existed at $60 \%$ of the study sites. In Zimbabwe R. appendiculatus is confined to the moister regions, which includes the highveld. The related $R$. zambeziensis replaces $R$. appendiculatus in the hot, dry river systems in the lowveld of Zimbabwe (Norval, Walker \& Colborne 1982; cited by Mooring \& Mazhowu 1995). Madder, Speybroeck, Bilounga, Helleputte \& Berkvens (2005) stated that survival of $R$. zambeziensis was better than that of $R$. appendiculatus under more extreme conditions of humidity and temperature. As such, R. zambeziensis was more adapted to hotter and drier areas while $R$. appendiculatus was more adapted to cooler and wetter conditions. In Zimbabwe and other countries within the region, the different instars of $R$. appendiculatus exhibit a strict pattern of seasonal occurrence (Latif, Hove, Kanhai, Masaka \& Pegram 2001), with one generation occurring each year. Adults are mostly active and abundant in the rainy season (mid-December to May), larvae in the cool season (March to October) and nymphs in the dry months of June to October (Latif et al. 2001).

Competitive displacement between the two species possibly occurs in those areas where their distributions overlap (Mooring \& Mazhowu 1995). There is an apparent displacement of $R$. appendiculatus by $R$. zambeziensis as one proceeds southward in the study area. Of the $R$. appendiculatus specimens collected, $84 \%$ were from Sivume diptank, the northern-most study site, as compared to $4.8 \%$ of $R$. zambeziensis collected at the same study site. In contrast, ca. $49 \%$ of $R$. zambeziensis specimens were collected at Double Cross Farm, the southernmost study site, but no $R$. appendiculatus were collected at that location. Although $R$. zambeziensis was collected from all sites on the animal, except the leg, $83 \%$ of the specimens were collected from the neck and pinna. In contrast, $69 \%$ of $R$. appendiculatus was collected from the lower perineum. The location at extreme ends of the host, of these two related ticks could be due to chemicals emitted by either tick species, which serve to repel the other related species.

According to the Animal Health Act (Cattle Cleansing) regulations (Government of Zimbabwe 1993), tick infestation arises when at least $10 \%$ of the cat- tle have $\geq 10$ live ticks on them. In this study, $81 \%$ of the cattle were regarded as tick infested. Five of the six study sites (ca. $83 \%$ ) were regarded as tick infested properties as more than $10 \%$ of the cattle had $\geq 10$ ticks. Generally, such properties would be placed under quarantine until the animals were tick free. Cattle can become tick infested if they are not regularly dipped or if ticks have developed resistance to the acaricide being used. The low level of tick infestation $(6 \%)$ at Blanket Farm could have been due to dipping that had taken place 2 days previously. Interestingly, at the other sites such as Double Cross Farm and Timber Farm where dipping had taken place 3 days previously, the herds were deemed to be tick infested as more than $10 \%$ of the cattle had $\geq 10$ live ticks. At these sites one would have expected the residual effect of the acaricide to kill or repel the ticks, but this was not the case. An abundance of live ticks on cattle even after recent dipping can occur for various reasons, amongst others, development of resistance to the particular acaricide being used (Meltzer \& Norval 1993), or poor mixing of the acaricide. The other factor that can contribute to increased tick abundance on cattle, even after regular and recent dipping, is the abundance of the free-living stages in the veld, which could be due to favourable environmental conditions. As this study was conducted during summer, it would be expected that free-living stages would be in abundance in the veld and that the pick-up rate of ticks from the veld would be correspondingly high.

\section{Udder and teat damage}

Farmers view tick infestations as causes of teat damage (Masika, Sonandi \& van Averbeke 1997; Hlatshwayo \& Mbati 2005). Ticks also cause udder damage, predispose to mastitis, abscessation and hide damage (Meltzer \& Norval 1993; Dreyer et al. 1998a; Dreyer et al. 1998b; Tibary \& Anouassi 2000).

Of the 286 milking cows and heifers sampled in this study, $53 \%$ had some degree of udder and/or teat damage. This is in agreement with results from Kenya (Latif, Punyna \& Capstick 1987, cited by Meltzer \& Norval 1993), where $52 \%$ of the milking cattle surveyed had lost one or more teats. While no teats were reported lost in the current study, teat and udder damage was encountered in the form of blocked teats, pus discharges and indurations of quarters. The reason teats not being lost is that farmers at most of the properties surveyed practised some form of regular tick control. If a breakdown in tick 
control, for whatever reason, were to occur for a prolonged period, then the prevalence of lost teats would emerge as an important issue.

Cows of lower to middle parity were the ones most affected by conditions of udder and teat damage. This differed from findings in Mozambique, where it was found that animals $>4$ years old were more prone to damage (Asselbergs \& Lopes Pereira 1989, cited by Meltzer \& Norval 1993). The reason for the apparent difference could be due to the method of estimating age of the animals. In this study, animals were aged according to parity rather than actual years. As such, the lower and middle parity groups included cows $>4$ years old, making comparison with the Kenyan study impossible. Of concern, was the fact that farmers treated only four $(2.6 \%)$ of the 152 animals with udder/teat damage. This low rate of treatment was due to lack of remedies and the fact that farmers were content as long as there was at least one functional quarter and teat from which a calf could suckle.

In conclusion, tick infestation as defined by the Animal Health Act of Zimbabwe (Government of Zimbabwe 1993) was prevalent in the milking cattle sampled, especially in communal herds of Gwanda. Such a situation is ideal for the establishment of endemic stability to the various TBDs. On the other hand, higher tick infestations can lead to damaged udders and teats, which was not deemed important by the farmers, since only a small proportion of them treated their affected animals. This attitude would change if communal farmers became commercially oriented and took into consideration potential productivity losses associated with certain levels of tick infestation and the effect on the growth rates of calves suckling from two or fewer teats and quarters. Tick species such as $R$. appendiculatus and $R$. zambeziensis were found in considerable numbers, but the disease that they transmit, theileriosis, has not been reported from the study area. Nevertheless, these cattle are at risk of contracting the disease should a Theileria parva-infected animal be introduced into the area. Currently these ticks are important in the study area for the direct damage that they cause.

\section{ACKNOWLEDGEMENTS}

We thank the Director of the Division of Veterinary Field Services, Dr Msongelwa Mangena, the Provincial Veterinary Officer for Matabeleland South, who availed all the resources needed to successfully conduct the study, and the Central Veterinary
Laboratory staff who assisted in tick identification. The assistance of the communal and commercial farmers at the various dip-tanks and farms is greatly appreciated for allowing access to their animals and their time. This project (V027-07) was approved by the Research Committee of the Faculty of Veterinary Science and the Animal Use and Care Committee of the University of Pretoria.

\section{REFERENCES}

BAKER, M.K. \& DUCASSE, F.B.W. 1967. Tick infestation of livestock in Natal. 1. The predilection sites and seasonal variations of cattle ticks. Journal of the South African Veterinary Medical Association, 38:447-453.

BRYSON, N.R., TICE, G.A., HORAK, I.G., STEWART, C.G. \& DU PLESSIS, B.J.A. 2002. Ixodid ticks on cattle belonging to small-scale farmers at 4 communal grazing areas in South Africa. Journal of the South African Veterinary Association, 73:98-103.

CHATIKOBO, P., KUSINA, N.T., HAMUDIKUWANDA, H. \& NYONI, O. 2001. The effect of tick control on bovine dermatophilosis in a smallholder farming area of Zimbabwe. Zimbabwe Veterinary Journal, 32:32-40.

COLBORNE, J., NORVAL, R.A.I \& SPICKETT, A.M. 1981. Ecological studies on Ixodes (Afrixodes) matopi Spickett, Keirans, Norval \& Clifford, 1980 (Acarina: Ixodidae). Onderstepoort Journal of Veterinary Research, 48:31-35.

DOWER, K.M., PETNEY, T.N. \& HORAK, I.G. 1988. The developmental success of Amblyomma hebraeum and Amblyomma marmoreum on the leopard tortoise Geochelone pardalis. Onderstepoort Journal of Veterinary Research, 55: 11-13.

DREYER, K., FOURIE, L.J. \& KOK, D.J. 1998a. Individual host variations in tick infestations of cattle in a resource-poor community. Onderstepoort Journal of Veterinary Research, 65:291-296.

DREYER, K., FOURIE, L.J. \& KOK, D.J. 1998b. The efficacy of used engine oil against ticks on cattle. Onderstepoort Journal of Veterinary Research, 65:275-279.

GOVERNMENT OF ZIMBABWE 1993. Animal Health (Cattle Cleansing Regulations, 1993), Statutory instrument 250 of 1993: 1776-1777.

HAMEL, H.D. \& GOTHE, R. 1978. Influence of infestation rate on tick-paralysis in sheep induced by Rhipicephalus evertsi evertsi Neumann, 1897. Veterinary Parasitology, 4:183-191.

HLATSHWAYO, M. \& MBATI, P.A. 2005. A survey of the control methods used by resource-poor farmers in the Qwa-Qwa area of the eastern Free State Province, South Africa. Onderstepoort Journal of Veterinary Research, 72:245-249.

HLATSHWAYO, M., MBATI, P.A. \& DIPEOLU, O.O. 2002. Seasonal abundance of adult ixodid ticks infesting cattle belonging to resource-limited farmers in the north-eastern Free State Province of South Africa. Onderstepoort Journal of Veterinary Research, 69:1-6.

HORAK, I.G., MacIVOR, K.M. DE F., PETNEY, T.N. \& DE VOS, V. 1987. Some avian and mammalian hosts of Amblyomma hebraeum and Amblyomma marmoreum (Acari: Ixodidae). Onderstepoort Journal of Veterinary Research, 54:397-403.

HORAK, I.G., POTGIETER, F.T., WALKER, J.B., DE VOS, V. \& BOOMKER, J. 1983. The ixodid tick burdens of various large 
ruminant species in South African nature reserves. Onderstepoort Journal of Veterinary Research, 50:221-228

HORAK, I.G., SWANEPOEL, R. \& GUMMOW, B. 2001. The distribution of Hyalomma spp. and human cases of CrimeanCongo haemorrhagic fever in South Africa. Proceedings of the $10^{\text {th }}$ Conference of the Association of Institutions for Tropical Veterinary Medicine, Copenhagen, Denmark, 2001 (not paginated).

INTERNATIONAL CROPS RESEARCH INSTITUTE FOR THE SEMI-ARID TROPICS 2007. Goat production and marketing: Baseline information for semi-arid Zimbabwe. Bulawayo: International Crops Research Institute for the Semi-Arid Tropics.

JONSSON, N.N. 2006. The productivity effects of cattle tick (Boophilus microplus) infestation on cattle, with particular reference to Bos indicus cattle and their crosses. Veterinary Parasitology, 137:1-10.

KATSANDE, T.C., MAZHOWU, W., TURTON, J.A. \& MUNODZANA, D. 1996. Babesia case reports and current distribution of Boophilus microplus in Zimbabwe. Zimbabwe Veterinary Journal, 27:33-37.

LATIF, A.A., HOVE, T., KANHAI, G.K., MASAKA, S. \& PEGRAM, R.G. 2001. Epidemiological observations of Zimbabwean theileriosis: Disease incidence and pathogenicity in susceptible cattle during Rhipicephalus appendiculatus nymphal and adult seasonal activity. Onderstepoort Journal of Veterinary Research, 68:187-195.

LAWRENCE, J.A., FOGGIN, C.M. \& NORVAL, R.A.I. 1980. The effects of war on the control diseases of livestock in Rhodesia (Zimbabwe). Veterinary Record, 107:82-85.

LONDT, J.G.H., HORAK, I.G. \& DE VILLIERS, I.L. 1979. Parasites of domestic and wild animals in South Africa. XIII. The seasonal incidence of adult ticks (Acarina: Ixodidae) on cattle in the northern Transvaal. Onderstepoort Journal of Veterinary Research, 46:31-39.

MADDER, M., SPEYBROECK, N., BILOUNGA, A., HELLEPUTTE, D. \& BERKVENS, D. 2005. Survival of unfed Rhipicephalus appendiculatus and Rhipicephalus zambeziensis adults. Medical and Veterinary Entomology, 19:245-250.

MASIKA, P.J., SONANDI, A. \& VAN AVERBEKE, W. 1997. Tick control by small-scale farmers in the central Eastern Cape Province, South Africa. Journal of the South African Veterinary Association, 68:45-48.

MEKONNEN, S., HUSSEIN, I. \& BEDANE, B. 2001. The distribution of ixodid ticks (Acari: Ixodidae) in central Ethiopia. Onderstepoort Journal of Veterinary Research, 68:243-251.

MELTZER, M.I. \& NORVAL, R.A.I. 1993. Evaluating the economic damage threshold for bont tick (Amblyomma hebraeum) control in Zimbabwe. Experimental and Applied Acarology, 17:171-185.

MELTZER, M.I., NORVAL, R.A.I. \& DONACHIE, P.L. 1995. Effects of tick infestation and tick-borne diseases infections (heartwater, anaplasmosis and babesiosis) on the lactation and weight gain of Mashona cattle in south-eastern Zimbabwe. Tropical Animal Health and Production, 27:129-144.

MOORING, M.S. \& MAZHOWU, W. 1995. Geographic distribution of ticks and comparison of tick load on male and female impala from three sites in Zimbabwe. Zimbabwe Veterinary Journal, 26:76-85.

NORVAL, R.A.I. 1979. Tick infestations and tick borne diseases in Zimbabwe Rhodesia. Journal of the South African Veterinary Association, 50:289-292.

NORVAL, R.A.I. 1981. The ticks of Zimbabwe. III. Rhipicephalus evertsi evertsi. Zimbabwe Veterinary Journal, 12:31-35.
NORVAL, R.A.I. 1983a. Arguments against intensive dipping. Zimbabwe Veterinary Journal, 14:19-25.

NORVAL, R.A.I. 1983b. The ticks of Zimbabwe. VII. The genus Amblyomma. Zimbabwe Veterinary Journal, 14:3-18.

NORVAL, R.A.I., SUTHERST, R.W., KURKI, J., GIBSON, J.D. \& KERR, J.D. 1988. The effect of the brown ear tick Rhipicephalus appendiculatus on the growth of Sanga and European breed cattle. Veterinary Parasitology, 30:149-164.

NORVAL, R.A.I., SUTHERST, R.W., JORGENSEN, O.G., GIBSON, J.D. \& KERR, J.D. 1989. The effect of the bont tick (Amblyomma hebraeum) on the weight gain of Africander steers. Veterinary Parasitology, 33:329-341.

NORVAL, R.A.I., PERRY, B.D. \& HARGREAVES, S.K. 1992. Tick and tick-borne disease control in Zimbabwe: What might the future hold? Zimbabwe Veterinary Journal, 23:1-14.

NORVAL, R.A.I., PERRY, B.D., MELTZER, M.I., KRUSKA, R.L. \& BOOTH, T.H. 1994. Factors affecting the distributions of the ticks Amblyomma hebraeum and A. variegatum in Zimbabwe: implications of reduced acaricide usage. Experimental and Applied Acarology, 18:383-407.

NORVAL, R.A.I., DONACHIE, P.L., MELTZER, M.I., DEEM, S.L. \& MAHAN, S.M. 1995. The relationship between tick (Amblyomma hebraeum) infestation and immunity to heartwater (Cowdria ruminantium infection) in calves in Zimbabwe. Veterinary Parasitology, 58:335-352.

PETER, T.F., PERRY, B.D., O'CALLAGHAN, C.J., MEDLEY, G.F., SHUMBA, W., MADZIMA, W., BURRIDGE, M.J. \& MAHAN, S.M. 1998a. Distribution of the vectors of heartwater, Amblyomma hebraeum and Amblyomma variegatum (Acari: Ixodidae), in Zimbabwe. Experimental and Applied Acarology, 22:725-740.

PETER, T.F., PERRY, B.D., O'CALLAGHAN, C.J., MEDLEY, G.F., SHUMBA, W., MADZIMA, W., BURRIDGE, M.J. \& MAHAN, S.M. 1998b. The distribution of heartwater in the highveld of Zimbabwe, 1980-1997. Onderstepoort Journal of Veterinary Research, 65:177-187.

PETNEY, T.N., HORAK, I.G. \& RECHAV, Y. 1987. The ecology of the African vectors of heartwater, with particular reference to Amblyomma hebraeum and Amblyomma variegatum. Onderstepoort Journal of Veterinary Research, 54:381-395.

REGASSA, A. 2001. Tick infestation of Borana cattle in the Borana province of Ethiopia. Onderstepoort Journal of Veterinary Research, 68:41-45.

STACHURSKI, F., MUSONGE, E.N., ACHU-KWI, M.D. \& SALIKI, J.T. 1993. Impact of Amblyomma variegatum on the liveweight gain of male Gudali cattle in Adamawa (Cameroon). Veterinary Parasitology, 49:299-311.

TAWONEZVI, P.H.R. 2005. Baseline study on the role of livestock in livelihood security in communal households in semiarid areas of Zimbabwe. Harare: Food and Agricultural Organisation.

THRUSFIELD, M. 1995. Veterinary Epidemiology. Cornwall: Butterworth \& Co.

TIBARY, A. \& ANOUASSI, A. 2000. Lactation and udder diseases, in Recent advances in Camelid Reproduction, edited by J.A. Skidmore \& G.P. Adams. International Veterinary Information Service. http://www.ivis.org (accessed January 2008).

VAN NIEKERK, D.J., FOURIE, L.J. \& HORAK. 2006. Birds as hosts of immature ixodid ticks in Free State Province, South Africa. Onderstepoort Journal of Veterinary Research, 73: 123-130. 
Tick infestation and udder and teat damage in cattle of Matabeleland South, Zimbabwe

WALKER, A.R., BOUATTOUR, A., CAMICAS, J.-L., ESTRADAPEÑA, A., HORAK, I.G., LATIF, A.A., PEGRAM, R.G. \& PRESTON, P.M. 2003. Ticks of domestic animals in Africa: A guide to identification of species. Edinburgh: Bioscience Reports.
YOUNG, D.L. \& HAANTUBA, H.H. 1997. An economic threshold model for controlling tick induced diseases and productivity losses in cattle. First European Conference for Information Technology in Agriculture, Copenhagen, 1997. 